\title{
KEKAYAAN SPESIES IKAN HASIL TANGKAPAN NELAYAN KECIL PADA AREAL PADANG LAMUN DI PERAIRAN PESISIR SEPANJANG PANTAI LOMBOK TENGAH
}

\section{TYPE OF FISH SPECIES FOR SMALL FISHERMAN CAPTURE IN THE PADANG LAMANG AREA IN COASTAL WATERS ALONG THE CENTRAL LOMBOK BEACH}

\author{
Nila Sari, Abdul Syukur* dan Karnan \\ Progran Studi Pendidikan Biologi FKIP Universitas Mataram, Mataram, Indonesia \\ Email: syukurbiologi@unram.ac.id
}

Diterima: 24 April 2020. Disetujui: 13 Mei 2020. Dipublikasikan: 9 Juni 2020

\begin{abstract}
Abstrak: Perikanan skala kecil adalah perikanan dengan ciri teknologi sederhana dan sangat tergantung pada lingkungan dan ekosistemnya, seperti ekosistem padang lamun. Tujuan penelitian adalah mengeksplorasi kekayaan spesies ikan hasil tangkapan nelayan kecil pada perairan padang lamun di sepanjang pantai Lombok Tengah. Pengambilan data ikan dari hasil tangkapan nelayan pada areal padang lamun dan data lamun menggunakan metode transek dan kuadran. Analisis data menggunakan analisis statistik diskriftif. Selain itu, dilakukan analisis keanekaragaman menggunakan Indeks Shannon-Wiener, keseragaman dengan Evennes Indeks dan dominansi dengan Simpson Indeks. Spesies lamun yang ditemukan adalah 10 spesies. Komposisi spesies ikan terdiri dari 22 famili dan 32 spersies. Sardinella gibosa dengan jumlah individu paling tinggi (21, 70 \%) dan yang paling rendah adalah adalah Gazza minuta, Lutjanus fulviflamma dan Paraplagusia blochi sebesar 0,07 \%. Lokasi dengan nilai Indeks Keanegaraman ikan paling tinggi adalah Teluk Kute $(2,39)$ dan yang paling rendah adalah Teluk Gerupuk (2,0). Indek ekologi lain, seperti indeks keseragaman (E) dan Dominansi (D) menujukkan bahwa tingkat keseragaman ikan berada pada katagori sedang dan tidak ada spesies ikan yang dominan. Asosiasi ikan dengan lamun dalah bukti ekologi peran lamun untuk mendukung keberlanjutan perikanan skala kecil di lokasi studi. Kesimpulan dari penelitian ini adalah kekayaan spesies ikan yang berasosiasi dengan lamun tidak hanya dapat menggambarkan nilai ekologi lamun, tetapi dapat berkontribusi positif untuk keberlanjutan matapencaharaian nelayan kecil. Oleh karena itu, kebijakan pengelolaan lamun adalah strategi untuk perlindungan biodiversity laut dan ekonomi masyarakat lokal.
\end{abstract}

Kata kunci: Lamun, Kekayaan Spesies ikan dan Nelayan Kecil

\begin{abstract}
Small-scale fisheries are fisheries with simple technological characteristics and are highly dependent on the environment and its ecosystem, such as seagrass ecosystems. The aim of the study was to explore the richness of fish species caught by small fishermen in seagrass waters along the coast of Central Lombok. Collecting fish data from fishermen's catches in the seagrass area, and seagrass data using the transect and quadrant method. Data analysis uses discrete statistical analysis. In addition, diversity analysis was performed using the Shannon-Wiener Index, uniformity with the Evennes Index and dominance with the Simpson Index. Seagrass species found were 10 species. The composition of fish species consists of 22 families and 32 species. Sardinella gibosa with the highest number of individuals $(21,70 \%)$ and the lowest are Gazza minuta, Lutjanus fulviflamma and Paraplagusia blochi by $0.07 \%$. The location with the highest fish index index was Kute Bay (2.39) and the lowest was Gerupuk Bay (2.0). Other ecological indices, such as the index of uniformity (E) and dominance (D) show that the level of uniformity of fish is in the medium category and there is no dominant fish species. The association of fish with seagrasses is an ecological proof of the role of seagrasses in supporting the sustainability of small scale fisheries in the study location. The conclusion of this study is that the richness of fish species associated with seagrasses not only can illustrate the ecological value of seagrasses, but can contribute positively to the sustainability of the livelihoods of small fishermen. Therefore, seagrass management policy is a strategy for the protection of marine biodiversity and the economy of local communities.
\end{abstract}

Keywords: Seagrass, Wealth Species of fish and Small Fishermen

\section{PENDAHULUAN}

Perikanan adalah sistem sosial-ekologi yang terintegrasi dalam sistem produksi, seperti yang dilaksanakan oleh nelayan skala kecil. Sistem produksi perikanan pada nelayan sekala kecil ditentukan oleh beberapa variable diantaranya adalah ketersediaan stok ikan, upaya penangkapan, alat tangkap dan ekosistemnya seperti ekosistm manrove, padang lamun dan terumnbu karang [1]. Karakter lain yang menjadi ciri sekala kecil adalah penggunaan teknologi rendah, akses terbuka, target tangkapan multi-spesies dan hasil tangkapan dapat di daratkan pada beberapa lokasi [2,3]. Dalam hal ini, keberadaan padang lamun memiliki kontribusi yang signifikan untuk mendukung perikanan sekala kecil, khususnya dalam hal keamanan pangan, matapencaharian, pengurangan kemiskinan, dan pembangunan pedesaan $[4,5]$. Berkaitan dengan hal ini perlindungan dan 
pelestarian lamun adalah usaha untuk keberlanjutan perikanan sekala di wilayah pesisir [6].

Ekosistem padang lamun adalah ekosistem di lingkungan laut dan berfunsgi secra signifikan untuk keragaman spesies ikan yang berasosisai ekosistem mangrove, terumbu karang dan ekosistem lainnya di wilayah pesisr [7], dan spesies ikan yang memanfaatkan ketiga ekosistem dalam siklus hidupnya adalah bukti ekologi konektivitas antar ekosistem di lingkuingan laut $[8,9,10,11]$, dan nilai konektivitas dari keragaman spesies ikan dapat menjadi dasar dalam memprediksi dampak hilangnya salah satu ekosistem terhadap terhadap keanekaragaman spesies ikan. Fungsi utama padang ekosistem padang lamun secara ekologi dan ekonomi adalah (1) padang lamun menyediakan habitat pemeliharan (nursery grouds) yang berharga untuk lebih dari 1/5 dari 25 perikanan terbesar di dunia, (2) perikanan skala kecil yang kompleks dari seluruh dunia telah membuktikan bahwa ushaa perikanan didukung oleh habitat lamun dan (3) aktivitas penangkapan ikan pada daerah intertidal, seperti pada padang lamun adalah fenomena global dan sering secara langsung mendukung mata pencaharian nelayan [12]. Hal ini menunjukkan keragaman jasa ekosistem lamun, meskipun ada variasinya yang dipengaruhi oleh kondisi georafis, spesies dan genus lamun [13].

Perairan pesisir Pulau Lombok memiliki potensi lamun, seperti di Teluk Kute dan Teluk urupk [14], dan keberadaan lamun sudah dikenal oleh masyarakat lokal [15]. Berkaitan dengan fungsi ekologi lamun terhadap ikan, status trofiknya dapat dikelompokkan dalam kelompok ikan carnivora, herbivora, planktivora dan omnivora [16], dan masyarakat lokal di wilayah pesisir Pulau Lombok, khususnya nelayan kecil matapencaharianya tergantung pada keberadaan padang lamun [17]. Namun demikian, penelitian tentang keragaman jenis ikan yang menjadi target tangkapan nelayan belum dilakukan. Oleh karena itu, dibutuhkan penelitian tentang kekayaan spesies ikan hasil tangkapan nelayan pada lokasi padang lamun di sepanjang pantai Lombok Tengah. Tujuan penelitian ini adalah untuk menggabarkan fungsi ekologi lamun terhadap kekayaan spesies ikan. Manfaat penelian ini adalah sebagai instrument dalam kebijakan pengelolaan ekosistem padang lamun dari aspek ekologi dan ekonomi, khususnya keberlanjutan matapencaharian nelayan kecil di lokasi studi dan lokasi lain yang relevan di Propinsi Nusa Tenggara Barat dan Indonesia.

\section{BAHAN DAN METODE \\ Waktu dan Lokasi Penelitian}

Penelitian ini telah dilakukan dari Maret sampai September 2019. Lokasi penelitian adalah wilyah pesisir Kabupaten Lombok Tengah. Masyarakat di lokasi studi sebagaian besar bermatapencahriannya sebagai nelayan kecil. Hal ini didukung oleh kondisi perairan laut yang subur dari suksesnya penanaman mangrove [18] dan keberadaan ekosistem lamun dengan jumlah 11 spesies di Teluk Kute dan Teluk Gerupuk [14]. Berkaitan dengan lokasi penelitian ditetapkan tiga lokasi yaitu Kuta, Gerupuk, dan Awang (Gambar 1). Ketiga lokasi penelitian saat ini, meskipun Kute dan Gerupuk telah menjadi kawasan wisata alam, namun masyarakat lokal masih mengandalkan matapencahriannya sebagai nelayan kecil masih dan di Teluk Awang masyarakat lokal matapencaharian adalah nelayan.

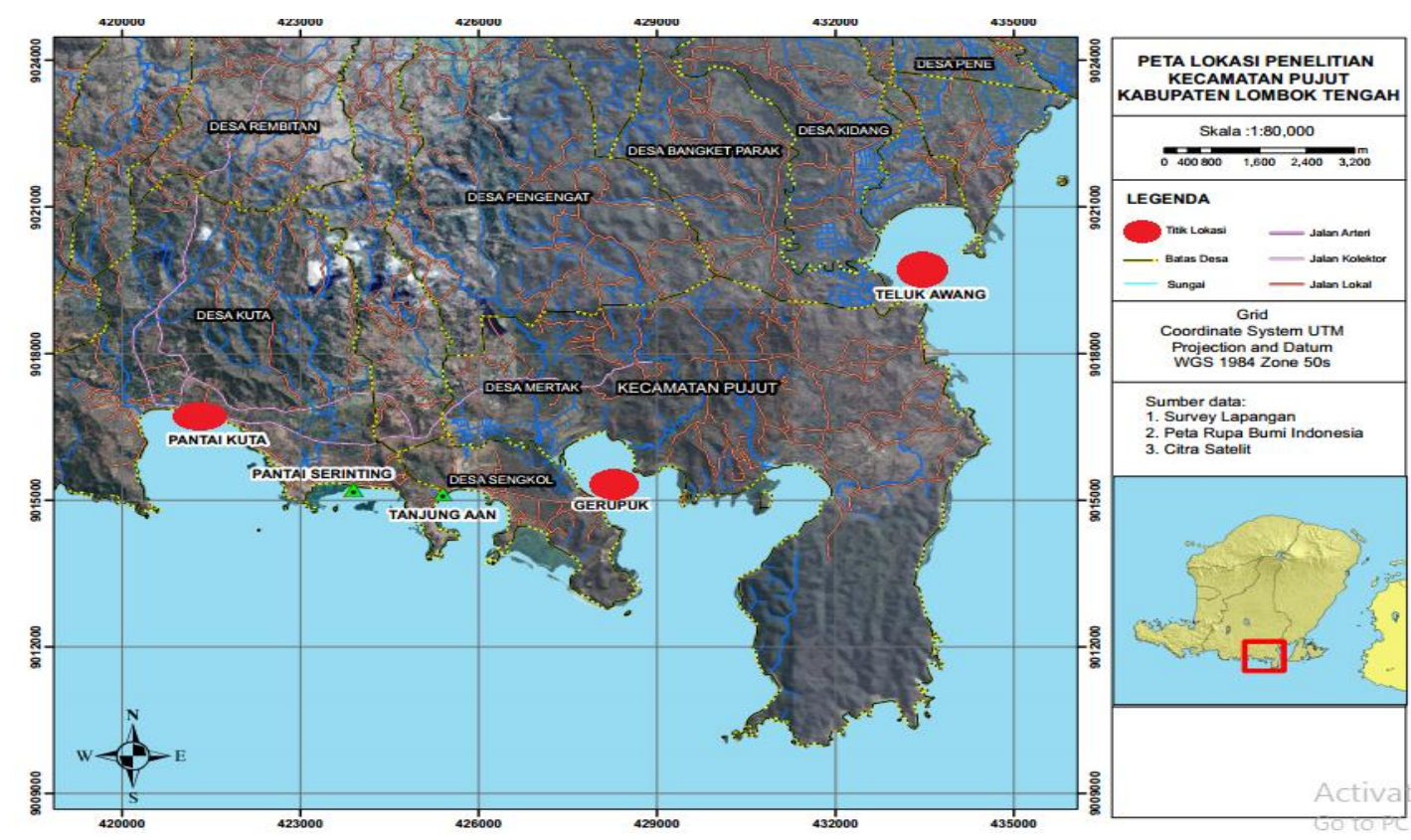

Gambar 1. Lokasi Penelitian 


\section{Pengabilan Data dan Analisis Data}

Pengambilan data ikan dilakukan selama periode penelitian yang bersumber dari hasil tangkapan nelayan pada tiap lokasi penelitian. Pemilihan nelayan ditentukan dengan teknik purposive sampling. Selanjutnya kriterianya adalah : (1) matapencahrian sebagai nelayan kecil, (2) melakukan penangkapan ikan pada areal padang lamun, (3) menjadi nelayan minimal 20 tahun dan (4) bersedia melakukan penangkapan dengan peneliti selama periode penelitian. Ikan hasil tangkapan dikumpulkan dan selanjutnya ditempatkan pada wadah yang telah disedikan. Variabel ikan yang menjadi objeks penelitian adalah jumlah spesies, jumlah individu/spesies pada tiap lokasi penelitian. Selain parameter ikan, pada penelitian ini dilakukan pengambilan data tentang lamun dengan menggunakan metode transek dan kuadran [19]. Pengambilan data lamun dilakukan pada saat air surut. Transek di letakkan tegak lurus garis pantai dan jarak antar transek adalah $50 \mathrm{~m}$, sedangkan jarak antar kuadran pada tiap transek adalah $25 \mathrm{~m}$. Pengamatan lamun di lakukan pada tiap kuadran dan variable lamun dicatat adalah jumlah spesies dan jumlah individu/spesies. Selanjutnya pada saat pengambilan data lamun dilakukan pengambilan data lingkungan yang meliputi: suhu, salinitas, $\mathrm{pH}$, kecerahan, kecepatan arus dan kedalaman substrat.

Analisi data penelitian, semua data penelitian dianalisis menggunakan analisis statistik diskriptif. Selain itu, ikan yang diperoleh duidentifikasi spesiesnya dan berpedoman dari [20]. Selanjutnya, analisis kekayaan spesies, keanekaragaman spesies dengan menggunakan Indeks Shannon-Wiener, keseragaman spesies dengan menggunakan Evennes Indeks dan dominansi spesies dengan menggunakan Simpson Indeks [21]. Sementara itu, identifikasi dan penentuan \% tutupan lamun berpedoman pada [22], dan analisis data lingkungan dilakukan secara exsitu atau secara langsung di lapangan.

\section{HASIL DAN PEMBAHASANS \\ Komposisi Spesies Lamun dan Kondisi Lingkungan di Lokasi Studi}

Spesies lamun yang ditemukan selama periode penelitain adalah yang ditemukan pada tiga lokasi penelitian adalah 10 spesies (Tabel 1) dan di Teluk Awang adalah yang paling rendah dengan 7 spesies. Hasil penelitian ini berbeda dengan jumlah spesies lamun pada tahun 1994 di Teluk Kute 11 spesies dan Teluk Gerupuk 10 spesies [14]. Perbedaan jumlah spesies dapat disebabkan oleh perbedaan stasiun pengamatan, dimana di lokasi studi belum ada stasiun permanen untuk monitoring perubahan kondisi lamun. Namun demikian, jumlah spesies lamun lebih tinggi dari jumlah spesies lamun di perairan pesisir Lombok Timur yaitu 9 spesies [23, 24, 25].

Spesies lamun di lokasi studi (Tabel 1) adalah kekayaan spesies lamun yang ditemukan pada lokasi studi. Berkaitan dengan sebarannya, lamun di lokasi studi memiliki sebaran sampai tubir pantai. Namun demikian dari luas sebaran menunjukkan di Teluk Awang memiliki sebaran yang paling luas, meskipun dengan panjang sebaran paling pendek \pm $470 \mathrm{~m}$. Hal ini disebabkan Teluk Awang memiliki panjang pantai $\pm 3 \mathrm{~km}$. Selanjutnya, Teluk Kute dari hasil pengukuran diperoleh panjang sebaran lamun adalah $520 \mathrm{~m}$ dan Teluk Gerupuk $480 \mathrm{~m}$. Sementara itu, keberadaan lamun pada lingkungan laut, khususnya yang berkaitan dengan pertumbuhan, produktivitas dan distribusi sebagaian besar dipengaruhi oleh ketersediaan cahaya. Hasil pengukuran kondisi lingkungan pada beberapa parameter selama periode penelitian Gambar 2 .

Tabel 1. Jenis Lamun Pada Tiap Lokasi Padang Lamun di Pesisir Lombok Tengah

\begin{tabular}{clccc}
\hline \multirow{2}{*}{ No } & \multicolumn{2}{c}{ Jenis Lamun } & \multicolumn{3}{c}{ Lokasi } \\
\cline { 3 - 5 } & & Awang & Gerupuk & Kute \\
\hline & & + & + & + \\
2 & Enhalus acroides & + & + & + \\
3 & Cymodocea rotundata & + & + & + \\
4 & Symodocea serulata & + & + & + \\
5 & Halodule pinifolia & + & + & + \\
6 & Halodule uninervis & + & + & + \\
7 & Halophila ovalis & + & + & + \\
8 & Halophila minor & - & + & + \\
9 & Halophila spinulosa & - & + & + \\
10 & Thalassia hemprinchii & - & + & + \\
\hline
\end{tabular}

Keterangan :+ = Ada, $-=$ Tidak ada 


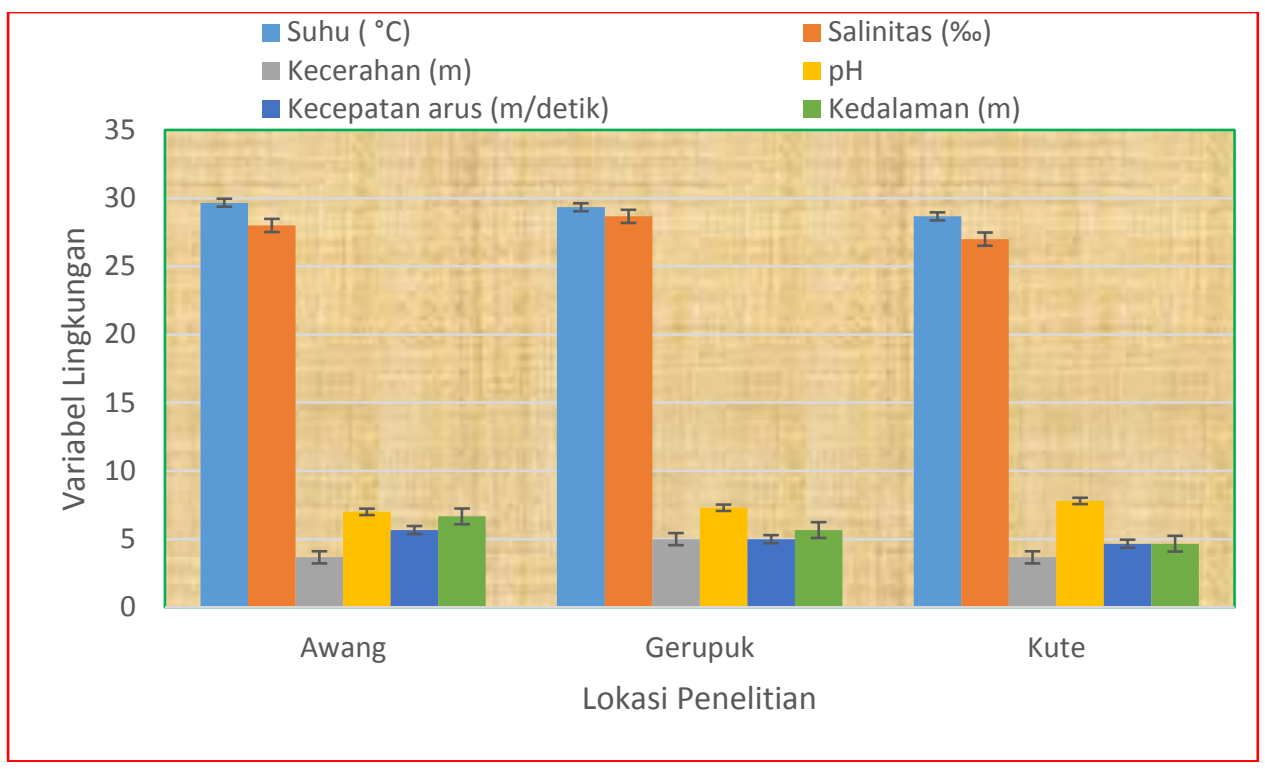

Gambar 2. Rata-rata hasil pengukuran parameter lingkungan selama periode penelitian

Parameter cahaya adalah factor dominan dalam menentukan kelimpahan dan distribusi lamun. Selain itu, lamun di lingkungan laut dapat mengalami stres akibat kurangnya cahaya yang disebabakan oleh meningkatnya aktivitas antropogenik di sekitar wilayah pesisir [26, 27, 28]. Nmaun demikian, lamun adalah salah satu spesies yang memiliki kemampuan pulih akibat dari stressor atau gangguan yang bersumber dari alam dan antropogenik [29]. Sementara itu, suhu dan salinitas adalah dua variable lingkungan yang memiliki pengaruh terhadap produktivitas lamun dan hasil pengukuran ke dua parameter (Gambar 2). Pada hasil penelitian ini kedua parameter berada pada kisaran yang normal untuk pertumbuhan dan distribusi lamun di lokasi studi. Suhu dan salinitas memiliki pengaruh terhadap pengaturan toleransi fisiologis dalam mengatur kelimpahan, distribusi spesies, perubahan komposisi dan kepadatan spesies. Faktor lain yang yang memiliki pengaruh terhadap distribusi lamun adalah kecepatan arus, $\mathrm{pH}$ dan kedalaman,. Nilain hasil pengukuran ke tiga parameter masih berada pada batas tolerasi untuk pertumbuhan dan produktivitas lamun serta distribusinya di lokasi studi.

\section{Komposisi dan Kekayaan Spesies Ikan di Lokasi Studi}

Lokasi penelitian (Gambar 1) dan kekayaan spesies lamun (Tabel 1) telah berkontribusi, khususnya pada nelayan kecil. Hasil penenelian komposisi spesies ikan pada tiap lokasi padang lamun (Gambar 3). Sementara itu, jumlah spesies ikan yang ditemukan pada semua lokasi penelitian adalah 32 spesies dengan total jumlah individu 7025 , dan nilai rata-ratanya adalah 219. Sementara itu, spesies yang memiliki jumlah individu di atas nilai rata-rata adalah 12 spesies yaitu Sardinella gibbosa, Herklotsichthys quadrimaculatus, Sardinella lemuru, Gymnothorax richardsoni, Siganus canaliculatus, Epinephelus bontoides, Stolepholus commersonnii, Gerres abbreviates, Siganus guttaus, Tylosurus crocodilus, Chanos chanos dan Sphyraena flavicauda.

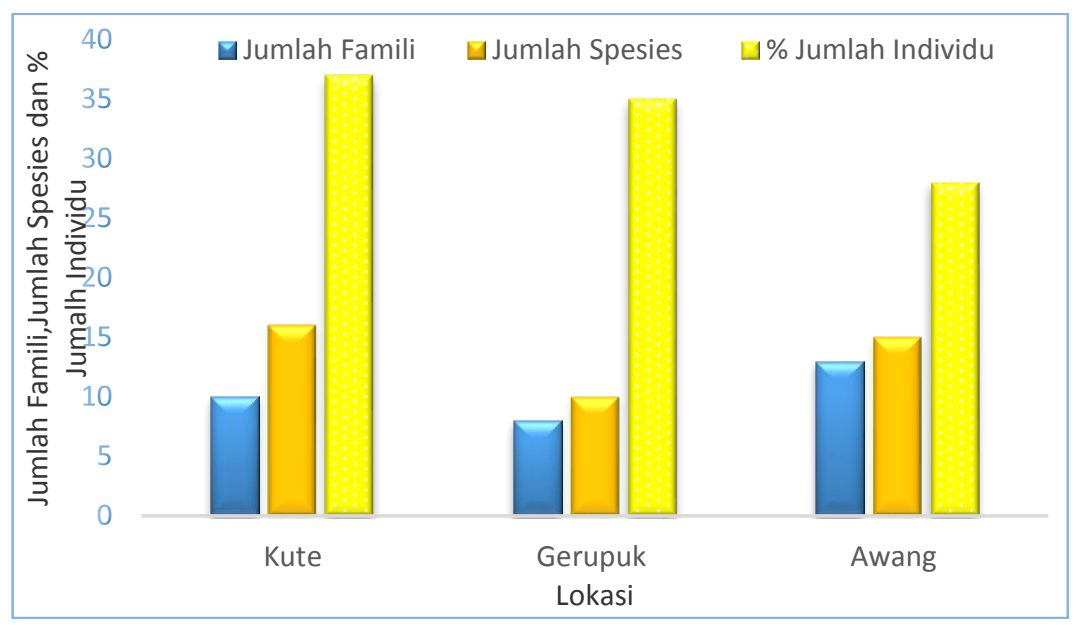

Gambar 3. Perbandingan komposisi jumlah family, spesies dan \% jumlah individu ikan di lokasi studi. 
Komposisi spesies ikan di lokasi studi yang terdiri dari 22 Famili dan 32 spesies dengan total jumlah individu 7025. Hasil analisis komposisi spesies beradasarkan jumlah individu (Gambar 4). Spesies ikan dengan jumlah individu yang paling tinggi adalah Sardinella gibbosa dari famili Clupeidae yang mencapai 21, $70 \%$, dan spesies yang jumlah individunya paling kecil adalah Gazza minuta dari famili Leiognathidae, Lutjanus fulviflamma dari famili Lutjanidae dan Paraplagusia blochi dari famili Cynoglossidae yaitu sebesar 0,07 \%. Selanjutnya, komposisi famili ikan dengan jumlah spesies yang paling tinggi adalah famili Clupeidae dengan 6 spesies yaitu Amblygaster sirm, Herklotsichthys dispilonotus,
Herklotsichthys quadrimaculatus, Ilisha striatula, Sardinella gibbosa, dan Sardinella lemuru. 72,72 \% famili terdiri dari satu spesies dan 22,72\% terdiri dari satu spesies. Komposisi spesies ikan di lokasi studi menggabarkan pentingnya keberadaan padang lamun bagi nelayan lokal. Hal ini dapat dilihat bahwa sebagain besar dari ikan hasil tangkapan nelayan adalah merupakan ikan ekonomis penting, terutama dari famili Siganidae dan beberapa family lain seperti family dari Scaridae, Lutjanidae, Mullidae dan Carangidae. Jumlah famili dan spesies ikan yang ditemukan di lokasi studi lebih rendah dari jumlah family dan spesies ikan di Teluk Ekas yaitu 35 spesies dan 28 famili [17,30,].

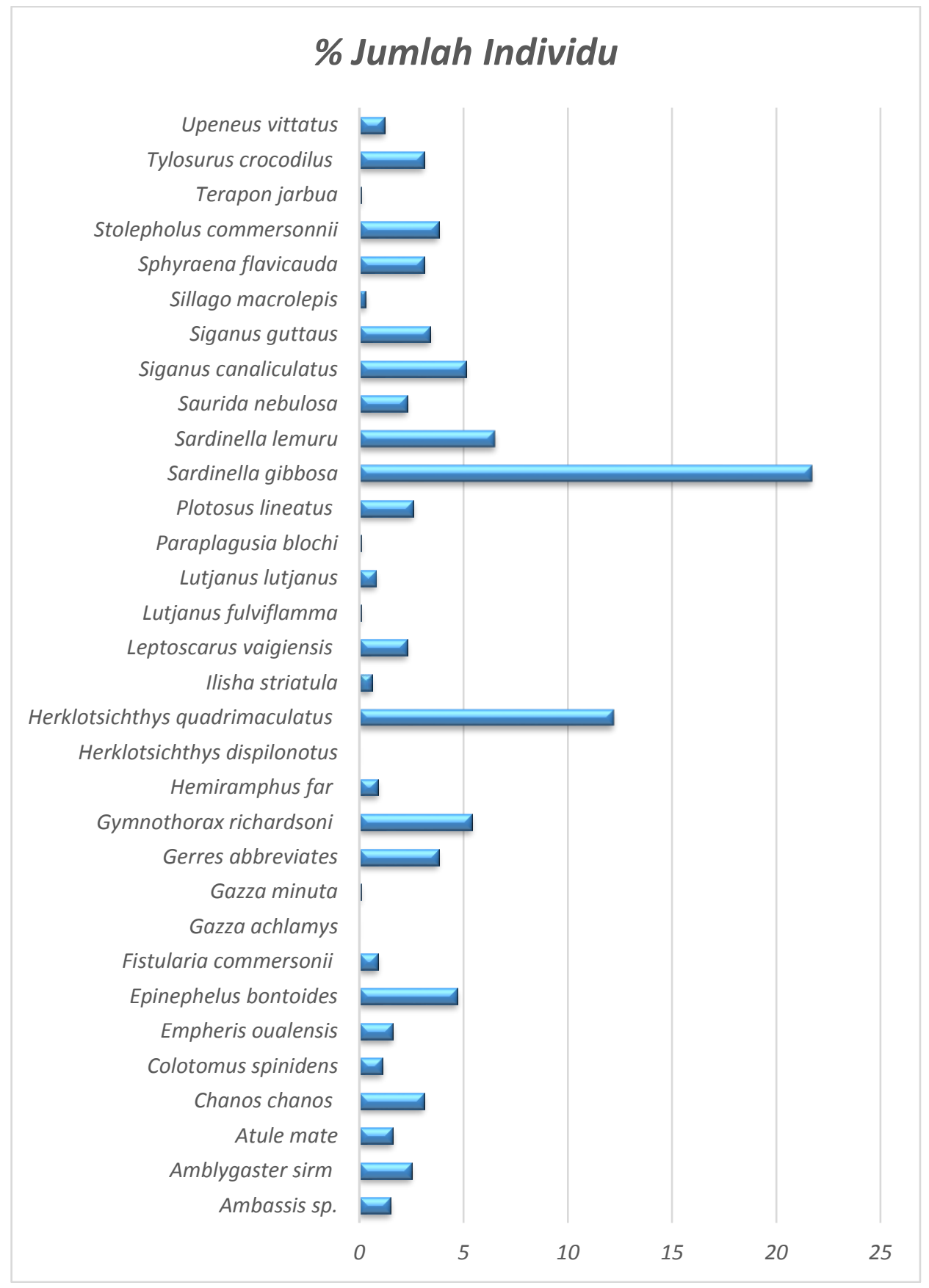

Gambar 4. Komposisi spesies berdasarkan \% jumlah individu di lokasi penelitian 


\section{Keanekaragaman, Keseragaman dan Dominasi Spesies Ikan di lokasi Studi}

Indikator ekologi fungsi lamun terhadap ikan adalah dari nilai indeks keanekaragaman, keseragaman dan dominansi ikan, dan dapat menggambarkan kekayaan spesies ikan. Hasil analisis ke tiga indikator untuk nilai keanekaragaman spesies ikan menunjukkan bahwa lokasi penelitian di Teluk Kute memiliki nilai keanekaramgan yang paling tinggi dan di Teluk Gerupuk adalah yang paling rendah dari tiga lokasi penelitian (Gambar 5). Hal ini dapat disebabkan oleh perbedaan komposisi spesies atau porporsi antara jumlah individu/spesies. Dalam hal ini, nilai keanekaragaman spesies adalah ekspresi dari struktur komunitas yang dipengaruhi oleh proporsi antar spesies secara keseluruhan dari suatu objeks penghukuran [31]. Aspek lain yang dapat dijelaskan dari nilai keanekaragaman ikan di lokasi studi adalah kekayaan spesies ikan sebagai indikator ekologi adalah nilai keberadaan lamun untuk keberlanjutan sumberdaya ikan. Berkaitan dengan hal ini, dimana lamun dapat berperan sangat penting, dinataranya adalah sebagai tempat pembesaran, mennyediaan makanan ikan, berlindung dari predator $[32,33,6]$.

Nilai indeks keanekaragaman ikan di lokasi studi berkisar antara $2-2,39$, beberapa hasil penelitian lain, seperti di Pulau Derawan Kalimantan Timur adalah anatara 0,84 - 2,22 [34], di kecamatan Wori Sulawesi Utara 1,70 - 2,59 [35], dan pada padang lamun di Gazi Bay Kenya berkisar antara 2,2 - 2,5 [36]. Lokasi lain seperti, pada padang lamun di wilayah pesisir Lombok Timur nilai keanekaramgan ikan berkisar antara 2,4 -2,9 [17]. Berkaitan dengan nilai keanekaragaman ikan yang berasosiasi dengan lamun adalah bagian yang sangat penting untuk agar dapat dipromosikan, khususnya untuk nelayan lokal dalam program konservasi padang lamun.

Indikator ekologi lain untuk menggabarkan kekayaan spesies lamun di lokasi studi adalah nilai indeks keseragaman. Indeks keseragaman fungsinya adalah untuk mengukur tingkat keseragaman spesies atau genera dalam komunitas. Dalam hal ini penyebaran jumlah individu tiap spesies atau genera tidak sama maka ada kecenderungan suatu komunitas menunjukan keseragaman spesies atau genera sama atau tidak ada spesies yang mendominasi. Hasil analisis Indeks keseragaman spesies ikan di lokasi berkisar antara 0,82 - 0,86 (Gambar 5). Dalam hal ini, keberadaan spesies ikan yang ditemukan di lokasi studi dari 32 spesies (Gambar 4) tidak ada spesies yang mendominansi.

Indeks dominnasi Simpson (D) spesies ikan hasil analisis dilokasi studi (Gambar 5). di Spesies Ikan di Perairan Pesisir Lombok Tengah yakni 0,02. Nilai Indeks Dominansi yang paling tinggi adalah di Teluk Kuta sebesar 0,05 dan yang paling rendah adalah di Teluk Gerupuk sebesar 0,002. Indeks dominansi fungsinya adalah untuk mengatahui ada atau tidak spesies yang dominasi menyusun suatu komunitas dalam ekosistem, seperti komunitas ikan pada padang lamun. Diskripsi nilai indeks dominasi adalah bila hasil pengukuran mendekati 0 maka tidak terdapat spesies yang mendominasi dan bila nilai hasil perhitingan mendekati 1, diduga ada spesies yang dominan. Dalam hal ini, Indeks dominansi (D) memiliki hubungan dengan indeks keanekaragaman, dimana jika nilai indeks dominansi tinggi maka indeks keanekaragaman akan rendah atau sebaliknya dan hilangnya suatu jenis yang dominan akan menimbulkan perubahan pada komunitas [21]. Namun demikian, spesies ikan Sardinella gibbosa persentasenya cukup tunggi, diamna di Teluk Gerupuk mencapai $36 \%$ dan Teluk Kute 25\%. Selanjutnya di Teluk Awang adsalah Sardinella lemuru mencapai $23 \%$. Oleh karena itu, family Clupeidae adalah family ikan yang paling dominan dengan indikator kelimpahan jumlah individu/spesies.

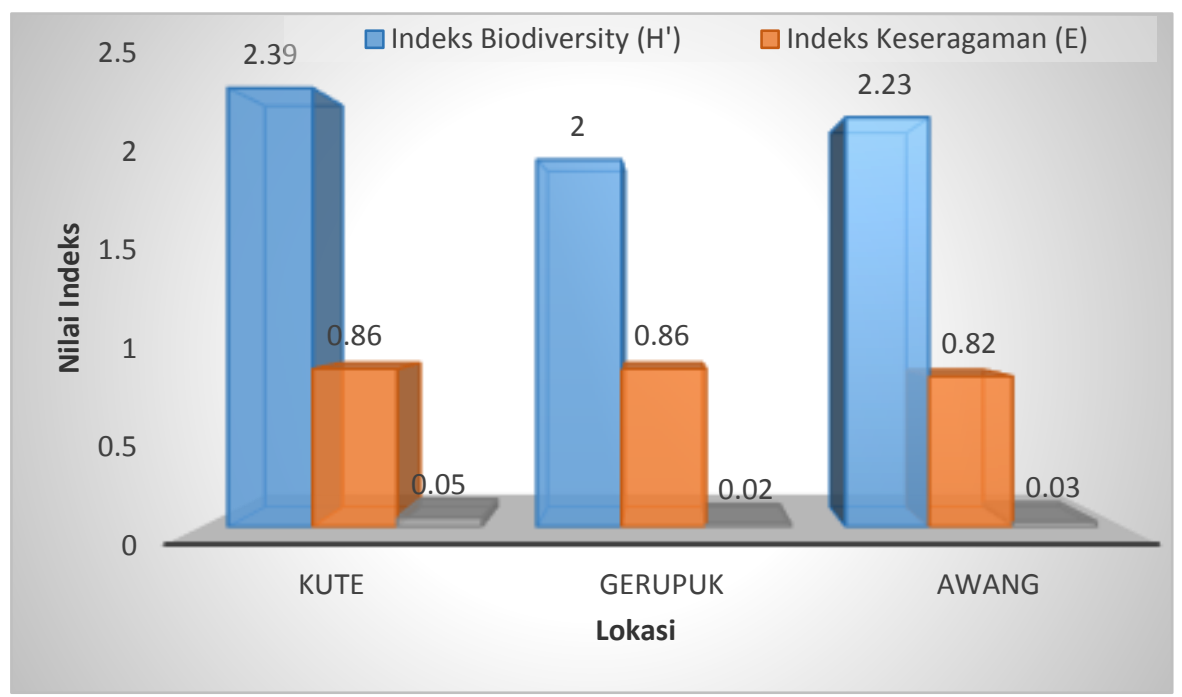

Gambar 5. Indeks Keanekaragaman, Keseragaman dan Dominansi spesies ikan di lokasi studi 


\section{KESIMPULAN}

Komposisi spesies lamun di lokasi studi terdiri dari 10 spesies atau sebesar 76, $92 \%$ dari 12 spesies lamun yang ada di perairan pesisir Indonesia. Kondisi lingkungan, seperti suhu, salinitas, $\mathrm{pH}$ dan kecerahan menunjukkan nilai yang sesuai untuk pertumbuhan dan distribusi lamun. Sementara itu, komposisi spesies ikan terdiri dari 32 spesies dengan 22 famili dan famili ikan dengan jumlah spesies paling tinggi adalah famili Clupeidae dan spesies dengan jumlah individu paling tinggi adalah Sardinella gibosa. Indikator ekologi lain, seperti indeks keanekarangan, keseragaman dan dominannsi spesies ikan dapat menjelasakan kekayaan spesies ikan yang berasosiassi dengan lamun di lokasi studi. Dalam hal ini, keberadaan lamun secara fungsional adalah sangat vital untuk keberlanjutan sumberdaya ikan.Selain itu, kehadiran kelompok ikan ekonimis penting pada lamun adalah menjadi faktor penting untuk matapencaharaian nelayan lokal di lokasi studi. Oleh karena itu, perlindungan lamun lamun tidak hanya berkaitan dengan perlindungan biodiversity tetapi dapat berhubungan dengan keberlanjutan matapencaharian nelayan kecil.

\section{UCAPAN TERIMA KASIH}

Penulis mengucapkan terima kasih kepada Kementrian Riset dan Teknologi yang memberikan dana penelitian melalui Skim Penelitian Dasar Unggulan Perguruan Tinggi Tahan Anggran 2019 dan pihak lain yang berkontribusi secara signifikan.

\section{DAFTAR PUSTAKA}

[1] Cullen-Unsworth, L. C., Nordlund, L. M., Paddock, J., Baker, S., McKenzie, L. J., \& Unsworth, R. K. (2014). Seagrass meadows globally as a coupled social-ecological system: Implications for human wellbeing. Marine Pollution Bulletin, 83(2), 387-397.

[2] McClanahan, T. R., \& Mangi, S. (2004). Gearbased management of a tropical artisanal fishery based on species selectivity and capture size. Fisheries Management and Ecology, 11, 51-60.

[3] de la Torre-Castro, M., Di Carlo, G., \& Jiddawi, N. S. (2014). Seagrass importance for a smallscale fishery in the tropics: The need for seascape management. Marine Pollution Bulletin, 83(2), 398-407.

[4] Akande, B., \& Diei-Ouadi, Y. (2010). Postharvest losses in small-scale fisheries. Food and Agriculture Organization of the United Nations.

[5] Nordlund, L. M., Unsworth, R. K., Gullström, M., \& Cullen-Unsworth, L. C. (2018). Global significance of seagrass fishery activity. Fish and Fisheries, 19(3), 399-412.

[6] Irawan, D., Supriharyono, Hutabarat, J., Ambariyanto. 2018. Seagrass beds as the buffer zone for fish biodiversity in coastal water of Bontang City, East Kalimantan, Indonesia. Biodiversitas ,19 (3): 1044-1053.
[7] Moussa, R. M., Bertucci, F., Jorissen, H., Gache, C., Waqalevu, V. P., Parravicini, V., \& Galzin, R. (2020). Importance of intertidal seagrass beds as nursery area for coral reef fish juveniles (Mayotte, Indian Ocean). Regional Studies in Marine Science, 33, 100965.

[8] Dorenbosch, M., Grol, M. G. G., Christianen, M. J. A., Nagelkerken, I., \& Van Der Velde, G. (2005). Indo-Pacific seagrass beds and mangroves contribute to fish density and diversity on adjacent coral reefs. Marine Ecology Progress Series, 302, 63-76.

[9] Unsworth, R. K., De León, P. S., Garrard, S. L., Jompa, J., Smith, D. J., \& Bell, J. J. (2008). High connectivity of Indo-Pacific seagrass fish assemblages with mangrove and coral reef habitats. Marine Ecology Progress Series, 353, 213-224.

[10] Bosire, J. O., Okemwa, G., \& Ochiewo, J. (2012). Mangrove linkages to coral reef and seagrass ecosystem services in Mombasa and Takaungu, Kenya (principatory modeling frameworks to understand wellbeing trade-offs in coastal ecosystem services: mangrove sub-component). ESPA, 45pp.

[11]Du, J., Xie, M., Wang, Y., Chen, Z., Liu, W., Liao, J., \& Chen, B. (2019). Connectivity of fish assemblages along the mangrove-seagrass-coral reef continuum in Wenchang, China. Acta Oceanologica Sinica, 1-10.

[12] Unsworth, R. K., Nordlund, L. M., \& CullenUnsworth, L. C. (2019). Seagrass meadows support global fisheries production. Conservation Letters, 12(1), e12566.

[13] Nordlund, L. M., Koch, E. W., Barbier, E. B., \& Creed, J. C. (2016). Seagrass ecosystem services and their variability across genera and geographical regions. PLoS One, 11 (10).

[14] Kiswara, W., \& Winardi, L. (1994). Keanekaragaman dan sebaran lamun di Teluk Kuta dan Teluk Gerupuk, Lombok Selatan. J. Teknologi Kelautan Nasional, 3(1), 23-36.

[15] Syukur, A. (2013). Pengetahuan Ekologi Masyarakat Lokal sebagai Indikator Penilaian Potensi Lamun (Seagrass) di Tanjung Luar Lombok Timur. Jurnal Biologi Tropis, 13(2).

[16] Syukur, A., Muchsin, Y. W. I., \& Kamal, M. M. (2014). Status Trofik Ikan yang Berasosiasi dengan Lamun (Seagrass) di Tanjung Luar Lombok Timur. Jurnal Biologi Tropis, 14(2): 162-170.

[17] Syukur, A., Wardiatno, Y., Muchsin, I., \& Kamal, M. M. (2017). Threats to seagrass ecology and indicators of the importance of seagrass ecological services in the coastal waters of East Lombok, Indonesia. American Journal of Environmental Sciences, 13(3), 251-265.

[18] Idrus, A. A., Syukur, A., \& Zulkifli, L. (2019, December). The livelihoods of local communities: Evidence success of mangrove conservation on 
the coastal of East Lombok Indonesia. In AIP Conference Proceedings (Vol. 2199, No. 1, p. 050010). AIP Publishing LLC.

[19] Khouw, A. S. (2009). Metode dan analisa kuantitatif dalam bioekologi laut. Penerbit: P4L dan Direktorat Jendral KP3K, Dep. Kelautan dan Perikanan RI. Ambon. pp 354

[20] Tsukamoto, K., Keiichi, M., \& Kurnaen, S. O. (1997). Fiel Guide to Lombok Island: Identification Guide to Marine Organisms In Seagrass Beds Lombok Island. Ocean Research Institut University of Tokyo, 445.

[21] Odum, E. P. (1993). Dasar-dasar ekologi edisi ketiga. Gadjah Mada Univesity Press, Yogyakarta.

[22] McKenzie, L. J. (2003). Guidelines for the rapid assessment and mapping of tropical seagrass habitats. Department of Primary Industries. The State of Queensland, 17-18.

[23] Syukur, A. (2015). Distribusi, Keragaman Jenis Lamun (Seagrass) dan Status konservasinya di Pulau Lombok. Jurnal Biologi Tropis, 15(2).

[24] Rahman, F. A., Qayim, I., \& Wardiatno, Y. (2018). Carbon storage variability in seagrass meadows of Marine Poton Bako, East Lombok, West Nusa Tenggara, Indonesia. Biodiversitas Journal of Biological Diversity, 19(5), 16261631.

[25] Hartini, H., \& Lestarini, Y. (2019). Pemetaan Padang Lamun Sebagai Penunjang Ekowisata di Kabupaten Lombok Timur. Jurnal Biologi Tropis, 19(1), 1-7.

[26] Dennison, W. C. (1987). Effects of light on seagrass photosynthesis, growth and depth distribution. Aquatic Botany, 27(1), 15-26.

[27] Dennison, W. C., Orth, R. J., Moore, K. A., Stevenson, J. C., Carter, V., Kollar, S., ... \& Batiuk, R. A. (1993). Assessing water quality with submersed aquatic vegetation: habitat requirements as barometers of Chesapeake Bay health. BioScience, 43(2), 86-94.
[28] Koch, E. W. (2001). Beyond light: physical, geological, and geochemical parameters as possible submersed aquatic vegetation habitat requirements. Estuaries, 24(1), 1-17.

[29] Macreadie, P.I., S.M. Trevathan-Tackett, C.G. Skilbeck, J. Sanderman, N. Curlevski, G. Jacobsen, and J.R. Seymour, 2015. Losses and recovery of organic carbon from a seagrass ecosystem following disturbance. Proceedings of the Royal Society B 282: 20151537.

[30] Karnan, K., Japa, L., \& Raksun, A. (2019). Struktur Komunitas Sumberdaya Ikan Padang Lamun di Teluk Ekas Lombok Timur. Jurnal Biologi Tropis, 15(1): 5 - 14.

[31] Brower JE, Zar JH \& Ende CNV. 1990. Field and laboratory methods for genera ecology. Fourth edition. McGraw-Hill Publications Boston: USA.

[32] Unsworth, R.K.F., Garrard, S.L., De Leon, P.S., Cullen, L.C., Smith, D.J., Sloman, K.A. and Bell, J.J. (2009) Structuring of Indo-Pacific fish assemblages along the mangrove-seagrass continuum. Aquatic Biology, 5, 85-95.

[33] Syahailatua, A dan Nuraini, S. (2011). Fish species composition in seagrass beds of Tanjung Merah (North Sulawesi), Indonesia. Marine Research in Indonesia, 36(2), 1-10.

[34] Marasabessy, M.D. 2010. Sumberdaya Ikan Di Perairan Padang Lamun Pulau-Pulau Derawan Kalimantan Timur. J. Oseanologi dan Limnologi Indonesia. 36 (2): 193-210

[35] Manik, N. 2011. Struktur Komunitas Ikan di Padang Lamun di Kecamatan Wori, Sulawesi Utara. Oseanologi dan Limnologi di Indonesia. 37 (1): $29-41$.

[36] Musembi, P., Fulanda, B., Kairo, J., \& Githaiga, M. (2019). Species composition, abundance and fishing methods of small-scale fisheries in the seagrass meadows of Gazi Bay, Kenya. Journal of the Indian Ocean Region, 15(2), 139-156. 